\title{
RETHINKING UNFAIR TRADING PRACTICES IN AGRICULTURE AND FOOD SUPPLY CHAIN: THE CROATIAN PERSPECTIVE
}

\author{
Vlatka Butorac Malnar, PhD, Associate Professor \\ University of Rijeka, Faculty of Law \\ Hahlić 6, 51000 Rijeka, Croatia \\ vlatka@pravri.hr
}

Mihaela Braut Filipović, PhD, Assistant Professor

University of Rijeka, Faculty of Law

Hahlić 6, 51000 Rijeka, Croatia

mbraut@pravri.hr

\author{
University of Rijeka, Faculty of Law \\ Hahlić 6, 51000 Rijeka, Croatia \\ azubovic@pravri.hr
}

Antonija Zubović, PhD, Associate Professor

\begin{abstract}
In recent years, the need for a systematic and harmonised way of preventing unfair trading practices (hereinafter UTPs) in the food supply chain has intensified at the European level due to many diverging national legislative solutions. These efforts resulted in the Directive 2019/633 on unfair trading practices (UTPS) in business-to-business relationships in the agricultural and food supply chain. Croatian UTPs Act, enacted already in 2017, was just amended to conform with the requirements of the named Directive. Generally speaking, the UTPs Act sets out rules and measures to prevent the imposition of UTPs in the food supply chain, establishes the list of such practices and sets up the enforcement structure and sanctions. Comparing the Directive to the UTPs Act, the authors discuss the outcome of the transposition pointing to the incorrect scope of application of the national legislation, its potential consequences and de lege ferenda solutions. Further, the authors anlyse the legal nature of the adopted UTPs system concluding that it does not fit into the traditional systematisation of laws jeopardising the coherency of the intricate and complex relationship between relating legislative frameworks. New rules are diverging and overlapping with both competition and contract law, leading to possible undesirable spill over effects in contract law, and unresolved concurring
\end{abstract}


competence with competition law. Authors suggest precautionary interpretative measures as a means of solving the identified legal conundrum.

Keywords: food supply chain, Directive 2019/633, unfair trading practices, UTPs

\section{INTRODUCTION}

The importance of the agricultural sector and the perseverance of the small farmers and farms is one of the EU policy's main goals. ${ }^{1}$ Tackling the issue of UTPs that seriously endanger farmers throughout the EU was on the EU legislator's agenda for some time. UTPs can be defined as a practice imposed unilaterally by a buyer concerning the sale of agricultural and food products to a supplier, using its significant bargaining power vis-à-vis the supplier, contrary to the principles of good faith and fair dealing, the principle of equality of arms in production and/ or trade of agricultural and food products. ${ }^{2}$ After more than ten years of discussion between the European Parliament, the European Commission, the Economic and Social Committee and Committee of the Regions, and various stakeholders the European Parliament and the Council on 17 April 2019 adopted Directive 2019/633 on unfair trading practices in business-to-business relationships in the agricultural and food supply chain (hereinafter UTP Directive) ${ }^{3}$ established at European level a common binding legal framework due to be transposed into national legislation by May 2021.

A key factor of UTPs is the existence of significant imbalances in bargaining power between suppliers and buyers of agricultural and food products. The UTP Directive aims at reducing the occurrence of UTPs in the food supply chain by introducing a minimum common standard of protection across the EU. The Directive's minimum harmonisation approach allows Member States to adopt or maintain national rules that go beyond the UTPs regulated by the Directive.

Before adopting the UTP Directive, only four MS had no specific regulation, with some MS that had several types of legislative instruments in place, alongside private regulation. The laws generally came in one or two varieties: amendments of the competition law (e.g., lower market dominance thresholds) or amendments

1 See Article 39 of the Treaty on the Functioning of the European Union (TFEU), OJ C 326, 26 October 2012, p. 47-390 (consolidated version)

2 Communication from The Commission to The European Parliament, The Council, The European Economic and Social Committee and The Committee of The Regions Tackling unfair trading practices in the business-to-business food supply chain, COM/2014/0472 final.

3 Directive (EU) 2019/633 of the European Parliament and of the Council of 17 April 2019 on unfair trading practices in business-to-business relationships in the agricultural and food supply chain [2019] OJ L 111 (UTP Directive) 
of the contract or commercial law (e.g., introducing special rules on B2B transactions or by extending the consumer protection rules to small businesses). The Republic of Croatia is one of the Member States that regulated this issue before adopting the UTP Directive by the Act on the prohibition of unfair trading practices in the B2B food supply chain ${ }^{4}$ (hereinafter UTPs Act) which entered into force on 7 December 2017. However, even before adopting the UTPs Act, some of the issues concerning UTPs were regulated by contract law, commercial law and to some extent by competition rules.

The goal of this paper is to analyse the relationship between these related legislative frameworks and identify possible areas of confusion. To that end, the authors first present an overview of the UTPs legislative framework, which is followed by an analysis of its relationship with competition and contract law.

\section{OVERVIEW OF THE UTPS LEGISLATIVE FRAMEWORK}

\subsection{Scope of application}

The very name of the UTP Directive suggests that it covers B2B relations in the agricultural and food supply chain. Because B2B relations are usually understood as relations between trades, it might be concluded that its personal scope of application is limited to traders, be it suppliers or buyers, who are involved in the food supply chain. However, the UTP Directive does not determine its personal scope of application in relation to traders, but instead to buyers and sellers. It defines a buyer as any natural or legal person, irrespective of that person's place of establishment, or any public authority in the EU buys agricultural and food products. ${ }^{5}$ Also, the term buyer may include a group of such natural and legal persons. ${ }^{6}$ Supplier means any agricultural producer or any natural or legal person, irrespective of their establishment, who sells agricultural and food products. ${ }^{7}$ The UTP Directive explicitly excludes the application of its provisions to agreements between suppliers and consumers. ${ }^{8}$

4 The Act on the prohibition of unfair trading practices in the business-to-business food supply chain, Official Gazette No. 117/2017

5 Article 3 (1) of the UTP Directive makes an exception for public entities providing healthcare regarding the prohibition on payment delays; it also makes an exception for payments made in the framework of school schemes described in Article 23 of Regulation 1308/2013.

6 Art. 2 (2) of the UTP Directive

7 Art. 2 (4) of the UTP Directive. Also, the term 'supplier' may include a group of such agricultural producers or a group of such natural and legal persons, such as producer organisations, organisations of suppliers and associations of such organisations

$8 \quad$ Art. 1 (2) of the UTP Directive 
In order to apply the provisions of the UTP Directive, the buyer must have a significant bargaining power. However, it has to be emphasised that UTP Directive is careful not to equate this power to the power usually addressed by the competition rules. The text does not refer to market power or a position of dominance; rather, it seems to address a different kind of power, namely buyers' relative bargaining power in the agri-food supply chain. ${ }^{9}$ The UTP Directive adopts the dynamic approach based on the relative size of the supplier and the buyer in terms of annual turnover. ${ }^{10}$ Asymmetry of turnover is conceived as a proxy for asymmetry of power. Therefore, when UTPs are carried by a buyer and supplier with the same level of turnover, they do not fall within the UTP Directive scope.

The UTP Directive covers trading relationships with a non-EU dimension. It applies to buyers established in the EU that trade with non-EU suppliers and buyers established outside the EU that trade with EU suppliers. Thus, the UTP Directive aims to avoid putting EU suppliers at a competitive disadvantage, which would happen if a trade is diverted to suppliers outside the EU. Another reason is to prevent forum shopping by buyers who might otherwise choose to establish themselves outside the EU to avoid compliance with the stricter rules. ${ }^{11}$

With the transposition of the Directive into Croatian legislation, the terms buyer and supplier have been harmonized so that the term buyer now includes the term wholesaler, processor, and retailer that have been defined in UTPs Act 2017. Since these are $\mathrm{B} 2 \mathrm{~B}$ relations, the question of the interpretation of the term trader in Croatian law arises. It should be noted that in Croatian law the definition of a trader is given in the Companies Act where a trader is defined as a legal or natural person who independently performs a permanent economic activity in order to make a profit by producing, trading goods or providing services on the market. ${ }^{12}$ A trader is also defined by the Trade Act as a legal or natural person registered to

9 Daskalova, V., Regulating Unfair Trading Practices in the EU Agri-food Supply Chain: a Case of Counterproductive Regulation?, Yearbook of Antitrust and Regulatory Studies, Vol. 13, No. 21, 2020, pp. 7-53, p. 13

10 Art. 1 (2) the UTP Directive identifies a schedule with five categories. Furthermore, the annual turnover of the suppliers and buyers shall be understood in accordance with the relevant parts of the Annex to Commission Recommendation 2003/361/EC of 6 May 2003 concerning the definition of micro, small and medium-sized enterprises [2003] OJ L 124

11 Daskalova, V., The New Directive on Unfair Trading Practices and EU Competition Law, Journal of European Competition Law \& Practice, Vol. 10, No. 5, 2019, pp. 281-296, p. 283

12 Art. 3 (1) of the Companies Act, Official Gazette No. 111/1993, 34/1999, 121/1999, 52/2000, 118/2003, 107/2007, 146/2008, 137/2009, 125/2011, 152/2011, 111/2012, 68/2013, 110/2015, $40 / 2019$ 
purchase and sell goods and / or provide services in trade. ${ }^{13}$ In the personal scope of application, the CCA took the position that in terms of UTPs Act participants in the food supply chain can be considered traders only with the cumulative fulfilment of the following conditions: - it is a natural or legal person registered to buy and sell goods within the meaning of the Trade Act, - who buys agricultural or food products in the observed relationship, - the purpose of purchasing these products is resale, - this person, together with his affiliated companies, generates the total annual income determined by the UTPs Act. ${ }^{14}$ Therefore, the CCA has adopted its own interpretation of the term trader for the purposes of applying the UTPs provisions. Thus, a natural or legal person could have the status of a trader under the Companies Act, but would not be a trader under the UTPs Act.

This raises the further question of whether the contract entered into by the contracting parties in the food supply chain is a commercial contract? According to Art. 14 (2) of the Obligations Act, commercial contracts are contracts concluded by traders among themselves in the performance of activities that are the subject of business activities of at least one of them or are related to the performance of those activities. ${ }^{15}$ Authors are of the opinion that in this case the term trader should be interpreted in accordance with the provisions of the Companies Act. So, if, for example, the supplier was an individual farmer, he would not have the status of a trader in accordance with the provisions of the Companies Act and the contract he would conclude with the supplier would not be a commercial contract but a civil contract. ${ }^{16}$ Thus, we conclude that the provisions on UTPs apply to both civil and commercial contracts.

We can also put this point of view in correlation with the provisions of the UTPs Act, according to which the bargaining power of the supplier is not determined at all, but only the buyer who is required to exceed the annual turnover of HRK 15 million (approximately EUR 2 million). This could lead to a situation where the

13 Art. 4 (1) of the Trade Act, Official Gazette No. 87/2008, 96/2008, 116/2008, 114/2011, 68/2013, $30 / 2014$

14 Ministry of Agriculture and Croatian Competition Agency, Odgovori na pitanja adresata Zakona o zabrani nepoštenih trgovačkih praksi u lancu opskrbe hranom, 2018, [http://www.aztn.hr/ea/ wp-content/uploads/2017/12/Pro\%C4\%8Di\%C5\%A1\%C4\%87eni-tekst-Odgovora-na-pitanja-adresata-Zakona-o-zabrani-nepo\%C5\%A1 tenih-trgova\%C4\%8Dkih-praksi-u-lancu-opskrbe-hranom-ZNTP-od-5102018..pdf], Accessed 20 March 2021

15 Obligations Act, Official Gazette No. 35/2005, 125/2011, 78/2015, 29/2018

16 See more Petrović, S., Pravni oblici pravnih osoba za obavljanje djelatnosti - pretpostavke i posljedice, Zbornik Pravnog fakulteta u Zagrebu, Vol. 56, special issue, 2006, pp. 87-127.; Braut-Filipović, M.; Zubović, A., Legal status of Croatian family farms, in: Sander, G.; Pošćić, A.; Martinović, A. (eds.), Exploring the Social Dimension of Europe, essays in honour of prof. Nada Bodiroga-Vukobrat, Verlag dr. Kovač, Hamburg, 2021, pp. 473-486. 
provisions of the UTPs Act protect a supplier who has the same or even higher bargaining power as a buyer. Such a scenario, which is possible under Croatian law, is not allowed by the provisions of the Directive which adopts five turnoverbased categories according to which protection is afforded and each of these categories explicitly requires the buyer and the supplier have different annual turnover.

Further uncertainty in determining whether a particular person is a trader are related to the performance of business activities. In this regard, the position of the CCA until the adoption of the amendments to the UTPs Act was that if the main activity of the buyer is not trade, or purchase of agricultural and food products, for their resale, he will not be considered a trader under the UTPs Act. ${ }^{17}$ However, it should be noted that the UTPs Act from 2017 in the definition of a trader required that it is a person "who buys agricultural and food products for resale" while the amendments to the UTPs Act in the definition of a buyer only refers to a person "who buys agricultural and food products". Thus, the CCA took the positions that persons performing catering activities are not considered traders, while amended definition of "supply chain of agricultural and food products" explicitly covers persons performing catering activities. Furthermore, regarding the position of public authorities, the definition of "buyer" now includes those public authorities that are defined as such in accordance with the regulations governing administrative disputes. ${ }^{18}$ However, it should be noted that the UTP Directive applies to all sales made to buyers which are public authorities, but provided that the supplier has a turnover not exceeding 350 million euros. ${ }^{19}$ This criterion is not adopted in Croatian law, which means that the provisions on UTPs will apply to public authorities as a buyer regardless of the turnover of the supplier.

We can conclude that by lowering the threshold of annual turnover ${ }^{20}$ and simplifying the determination of contractual parties, the new regulatory regime has significantly expanded its scope of application that has to be adjusted at the enforcement level. In addition, by retaining a threshold for only one contractual party - the buyer - the new UTPs Act fails to meet the basic principle underlying

17 Thus, for example, hotels were not subject to the application of the UTPs Act.

18 Art. 2 (2) of the Law on Administrative Disputes, Official Gazette No. 20/2010, 143/2012, 152/2014, $94 / 2016,29 / 2017$

19 Art. 1 (2) of the UTP Directive. The concept of public authority covers national, regional or local authorities, but also bodies governed by public law and associations formed by one or more such authorities or bodies, regardless of size. Daskalova, V., op. cit., note 11, p. 282

20 It has to be emphasised that under the UTPs Act from 2017 the threshold was much higher. The legislation applied to re-seller whose turnover in Croatia exceeds approximately EUR 13,3 million (HRK 100 million), and to processor/buyer whose turnover in Croatia exceeds approximately EUR 6,7 million (HRK 50 million). Thus, the assumption of the existence of a strong bargaining power has changed significantly. 
the Directive - assuring that it applies to situations of significant imbalances in bargaining power, as unequivocally explained by preamble of the Directive and its par. 1. Authors consider that such a regulatory choice, which may lead to the protection of a supplier with the same or even stronger bargaining power then the buyer, may not be regarded a higher protection granted under the minimum harmonisation standard of the Directive, but instead it amounts to its incorrect transposition. In that sense, de lege ferenda suggestion of the authors is the introduction of threshold for the supplier, which should be lower then that of the buyer, i.e. at least below HRK 15 million. In the meantime, in order to ensure the full effectiveness EU law, the potential illogical consequences of the scope of application of the UTPs Act must be avoided. This should be achieved by abiding to the principle of consistent interpretation of EU law, consisting of a duty of national courts and all other state bodies, including the CCA, to interpret national legislation designed to implement EU law, i.e. the UTPs Act, as far as possible, in light of the wording and the purpose of the UTP Directive as a legislation with which it is harmonised. ${ }^{21}$

\subsection{Types of prohibited UTPs}

Before adopting UTP Directive, UTPs have been often prohibited through the use of general clauses and general principles. ${ }^{22}$ The Directive focuses on prohibition of UTPs providing a "minimum list" of UTPs distinguishing between practices unfair per se („black list“) and practices that should be qualified unfair if not explicitly agreed upon in the supply contract („grey list“). For the latter the default rule prohibits the practice, but parties may overcome this prohibition if they expressly agree upon. Contract terms that allow for UTPs included in the "black list" or that admit "grey list" practices without complying with the requirements imposed by the UTP Directive may not be enforced. ${ }^{23}$

$21 \quad$ For a detailed account on the EU principle of consistent interpretation see Mišćenić, E., Europsko privatno prvo: opći dio, Školska knjiga, Zagreb, 2019, pp. 131 et seq.

22 For an overview of national legal frameworks see Cafaggi F.; Iamiceli, P., Unfair Trading Practices in the Business-to-Business Retail Supply Chain - An overview on EU Member States legislation and enforcement mechanisms, 2018, [https://iris.unitn.it/retrieve/handle/11572/204123/224121/JRC\%20Report\%20 (final).pdf], Accessed 10 March 2021, pp. 12-13, 14 pointing out that ,in the large majority of systems, general principles and general clauses are always complemented by either examples or more structured lists of prohibited practices falling under the umbrella of the general prohibition."

23 Art. 3 par. 4 of the UTP Directive. Cafaggi, F.; Iamiceli, P., Unfair Trading Practices in Food Supply Chains. Regulatory Responses and Institutional Alternatives in the Light of the New EU Directive, 2019, [https://ssrn.com/abstract=3380355], Accessed 10 March 2021, pp. 10 
The UTP Directive enumerates nine practices which are per se prohibited ('black list'): ${ }^{24}$ (a) payment delay, ${ }^{25}$ (b) abrupt order cancellation of perishable agricultural and food product, ${ }^{26}$ (c) unilateral changes of contract terms concerning frequency, method, place, timing or volume of the supply or delivery, quality standards, terms of payment or the prices or as regards the provision of services, (d) request for payments that are not related to the sale, ${ }^{27}$ (e) requests for payment concerning the deterioration or loss of agricultural and food products - that is not caused by the negligence or fault of the supplier - occurring on the buyer's premises or when ownership has passed to the buyer (f) refusal to confirm in writing the terms of a supply agreement ${ }^{28}(\mathrm{~g})$ unlawful use or disclosure of supplier's trade secret $(\mathrm{h})$ commercial retaliation against a supplier exercising contractual or legal rights, including filing a complaint or cooperating with enforcement authorities during an investigation $^{29}$ (i) request for compensation for the cost of examining customer complaints related to the sale of the supplier's products although there is no negligence or fault on the part of the supplier.

24 Art. 3 par. 1 of the UTP Directive

25 The Directive imposes a maximum payment term of 30 days for perishable agricultural and food products and 60 days for non-perishable agricultural and food products. The Late Payments Directive requires that businesses pay within 60 days, unless expressly agreed otherwise and unless that is grossly unfair, and that public authorities pay within 30 days or within 60 days (in exceptional circumstances). Directive 2011/7/EU of the European Parliament and of the Council of 16 February 2011 on combating late payment in commercial transactions [2011] OJ L 48/1

26 A period of less than 30 days is always considered as short notice. Daskalova, V., op. cit., note 11, p. 289 points out „A confusing element of the UTP Directive is the fact that the practice of returning unsold products to the supplier without paying for them or for their disposal is a practice featured on the grey list of practices. Specifically, Article 3(2) of the UTP Directive provides that parties can make agreements regarding returns. Given that returns are less strictly treated than cancellations, one may expect to see a lot more returns instead of order cancellations in the future since the former can be negotiated pursuant to a contract, whereas the latter are per se prohibited."

27 This type of UTPs raises the issue of interpretation of payments that are not related to sale. It will be necessary to withdraw the difference with the payments listed in the „grey list“ regulated in Art. 3 (2) of the Directive. This raises the question as to where the grey zone ends and where the "prohibition zone" begins.

28 The UTP Directive strengthens the already existing provisions under the common agricultural policy regulations. See Regulation (EU) 2017/2393 of the European Parliament and of the Council of 13 December 2017 [2017] OJ L 350/15.

29 The Preamble of the UTP Directive in par. 25 gives the following examples of reprisal: delisting of products, reducing the quantities of products, or suspending the provision of certain services such as marketing or promotion of supplier products. Daskalova, V., op. cit., note 11, p. 295 points out that this provision addresses the so called 'fear factor', which is deemed to be one of the major reasons why contract law enforcement, private voluntary schemes, and stricter unilateral conduct laws have failed to discipline buyers which systematically breach their contracts or act in bad faith toward their suppliers. Schebesta, H.; Purnhagen, K. P; Keirsbilck, B.; Verdonk, T., Unfair Trading Practices in the Food Chain: Regulating Right?, 2018, [https://ssrn.com/abstract=3267118], Accessed 25 March 2021 
Within the so called 'grey list', practices allowed if agreed upon in the contract concern the return of unsold products and the imposition to suppliers of certain fees (for stocking, displaying, listing, marketing, advertising, promotional activities, including discount initiatives, or for fitting-out premises for supplier's products). ${ }^{30}$ Article 3(2) of the UTP Directive does not take a stance as to whether the requests specified in its subparagraphs are fair or not, exploitative or exclusionary. ${ }^{31}$

With the UTP Directive transposition into Croatian legislation, all UTPs covered by the UTP Directive are included in the list of UTPs in Croatian law, so the application is expanded from the current 33 to 43 practices that are considered UTPs. The new regime regulates the obligations related to the written contract between the buyer and the supplier and the rules and responsibilities regarding the issuance of invoices and the redemption block.

\subsection{Enforcement}

Since UTPs may result in civil, administrative, and criminal infringements, the key issue is the regulation of enforcement regimes. The UTP Directive explicitly prescribes that MS should designate one or more enforcement authorities to ensure the effective enforcement of the prohibited UTPs. ${ }^{32}$ The enforcement triangle, including judicial, administrative and private resolution mechanisms, represents a relatively common feature in MSs. ${ }^{33}$ The UTP Directive focuses on administrative enforcement, providing authorities with additional power to investigate and to sanction both domestic and cross-border UTPs. Enforcement authorities may carry on own investigations stimulated by affected parties or initiate ex officio proceedings (Art. 6 (1) of the UTP Directive). Furthermore, MS must ensure that enforcement authority has the power to carry out unannounced on-site inspections within the framework of its investigations, in accordance with national rules and procedures as well as the power to impose, or initiate proceedings for the imposition of, fines and other equally effective penalties and interim measures on the author of the infringement. The penalties should be effective, proportionate and dissuasive, taking into account the nature, duration, recurrence and gravity of the infringement. An innovative element of the UTP Directive is the possibility for producer organisations and other organisations representing (or having a legiti-

\footnotetext{
$30 \quad$ Art. 3 par. 2 of the UTP Directive

31 Daskalova, V., op. cit., note 11, p. 295

32 According to Article 4 (2) of the UTP Directive „If a Member State designates more than one enforcement authority in its territory, it shall designate a single contact point for both cooperation among the enforcement authorities and cooperation with the Commission."

33 For an overview of main enforcing authorities in MS before the adoption of the UTP Directive see Cafaggi F.; Iamiceli, P., Unfair..., op. cit, note 21, p. 18
} 
mate interest in representing) suppliers to submit complaints. ${ }^{34}$ Since most supply chains expand cross-border in the Art. 8 of the UTP Directive has prescribed the obligation of cooperation among enforcement authorities.

Croatian UTPs Act from 2017 empowered the CCA for the enforcement of its provisions. The CCA carries out the administrative proceeding to establish abuse of superior bargaining power by imposing UTPs and the administrative proceeding for setting and imposing the fines. The CCA may initiate the proceeding $e x$ officio or upon the request of the party. From the entry into force of the UTPs Act until the end of 2019, CCA initiated 223 cases, of which 187 had the status of non-administrative cases. During 2019, nine administrative proceedings were completed with the issuance of seven decisions, in which it was established that the parties, using significant bargaining power, imposed UTPs on their suppliers within the meaning of the UTPs Act and imposed administrative penalties in the total amount of HRK 3,499,500.00.35

\section{BACK TO THE BASICS: LEGAL SYSTEMATIZATION OF THE NEW RULES ON UTPS}

Every legal system strives towards a coherent systematization of legal norms. ${ }^{36}$ There are plenty of classification criteria, but one of the most important ones is according to the content of legal norms. ${ }^{37}$ Such systematization serves multiple functions, including facilitating the applicable legal norm to a concrete legal relationship; the detection and elimination of contradictions and illegalities between different legal norms, and, particularly, the systematic interpretation of legal norms. ${ }^{38}$ "In systematic interpretation, one attempts to clarify the meaning of a legal provision by reading it in conjunction with other, related provisions of the same section, or title, of the legal text, or even other texts within or outside the given legal system; thus, this method relies upon the unity, or at least the con-

\footnotetext{
34 Art. 5 (2) of the UTP Directive

35 Croatian Parliament, Explanatory memorandum of the Draft Law on the Amendments to the UTPs Act, 2021, [https://www.sabor.hr/hr/prijedlog-zakona-o-izmjenama-i-dopunama-zakona-o-zabrani-nepostenih-trgovackih-praksi-u-lancu], Accessed 2 April 2021

36 According to Visković „the term system of legal norms (or legal system) denotes primarily two different but also related things: hierarchical arrangement of legal norms and scientific arrangement of legal norms” Visković, N., Teorija države i prava, Birotehnika, Zagreb, 2001, p. 267, 286.

37 This is the so-called scientific arrangement of legal norms defined as "the totality of positive and historical legal norms of a society, state and non-state, which are classified into units according to content, i.e. according to the types of social relations that they regulate.” Ibid., p. 268.

38 Loc. cit.
} 
sistency, of the legal world." 39 The importance of such an interpretation cannot be overstated. It directly influences the achievement of an efficient and coherent enforcement and "in the juridical perspective, the logical coherency of the system becomes the necessary guarantee for non-arbitrary decisions." ${ }^{40}$

In light of these observations, we start off the analysis with the fundamentals - the legal systematization of the new rules on UTPs in B2B relationships in the agricultural and food supply chain. As will be demonstrated below, this is not such an easy task. It is unclear from the theoretical point of view the appropriate legal systematization of these rules and how they interrelate with other complementary rules in the national legal system.

At the EU level, consumer law has already addressed the injustice arising out the unequal bargaining power between the contractual parties, ${ }^{41}$ which doES not extend to $\mathrm{B} 2 \mathrm{~B}$ relations maily because as matter of principle, in commercial relations neither party is considered a weaker party in need of consumer -like legislative protection. On the other hand, general contract law and legislation directly related to B2B commercial relationships, such as the Directive concerning misleading and comparative advertising, only partially addresses the relevant issue. ${ }^{42}$ The same holds for the EU competition law which generally provide an excellent legal framework for combating distortions of competition which may as well arise from unequal bargaining power between contractual parties.

Article 101 TFEU, prohibits all agreements between undertakings, which may affect trade between Member States and which have as their object or effect the prevention, restriction or distortion of competition within the internal market. However, this legal ground has been of a limited importance when it comes to the agricultural sector, as the EU competition rules are subject to a number of deroga-

39 Brugger, W., Concretization of Law and Statutory Interpretation, Tulane European \& Civil Law Forum, Vol. 11, 1996, pp. 207-250, pp. 207, 237.

40 Caroccia F., Rethinking the Juridical System. Systematic Approach, Systemic Approach and Interpretation of Law, Italian Law Journal, Vol. 2, No. 1, 2016, pp. 65-85

41 Directive 2005/29/EC of The European Parliament and of the Council of 11 May 2005 concerning unfair business-to-consumer commercial practices in the internal market and amending Council Directive 84/450/EEC, Directives 97/7/EC, 98/27/EC and 2002/65/EC of the European Parliament and of the Council and Regulation (EC) No 2006/2004 of the European Parliament and of the Council ('Unfair Commercial Practices Directive') OJ L [2005] 29/1 amended by Directive (EU) 2019/2161 of the European Parliament and of the Council of 27 November 2019 amending Council Directive 93/13/EEC and Directives 98/6/EC, 2005/29/EC and 2011/83/EU of the European Parliament and of the Council as regards the better enforcement and modernisation of Union consumer protection rules (Text with EEA relevance), [2019] OJ L 327/7

42 Directive 2006/114/EC of the European Parliament and of the Council of 12 December 2006 concerning misleading and comparative advertising [2006] OJ L 376/21 
tions and exemptions in that sector on the grounds of Articles 39 and 42 TFEU. ${ }^{43}$ On the other side, Article 102 TFEU, protects competition from unilateral market power exercised by a dominant undertakings. However, below the dominance threshold, as understood under Article 102 TFEU, the unilateral conduct in question falls outside the scope of the of EU competition law. ${ }^{44}$ This is due to the belief that if not dominant, an undertaking is prevented from abusing its market power, because the competitive market forces assure the competitive equilibrium. As long as there are available alternative business partners, the unsatisfied party may turn to someone else making such business practice unprofitable.

The problem in the food and supply chain is that these market forces are not working properly because the market is highly concentrated, i.e. held in the hands of just a few very large retailers, making it difficult for suppliers to find alternatives. ${ }^{45}$ In addition, often SMEs involved in such contracts may find it difficult to exit, due to financial constraints in terms of loans they have to keep replaying. ${ }^{46}$ This enables strong retailers to systematically impose UTPs on their business partners, provoking a domino effect along the supply chain, as the latter is "a continuum of vertically inter-related markets." ${ }^{47}$ As a result, "the negative effect of a UTPs that occurs downstream, for instance between a retailer and a processor, thus can cascade backward in the chain to ultimately reach farmers." ${ }^{38}$

The existent legal gap, coupled with serious risks posed by these practices in the food supply chain, induced a sequence of EU Commission's recommendations

43 The underlying reason is the overriding importance of the Common Agricultural Policy (CAP) goals set out in Article $39 \mathrm{TFEU}$, as approved by the CJEU. The CAP derogations relate to periods of crisis, the general and product specific CAP derogation. In addition, there are exceptions relevant for activities of agricultural producers. These principles are specified in the Regulation (EU) No 1308/2013 of the European Parliament and of the Council of 17 December 2013 establishing a common organisation of the markets in agricultural products and repealing Council Regulations (EEC) No 922/72, (EEC) No 234/79, (EC) No 1037/2001 and (EC) No 1234/2007 (CMO Regulation). For a brief summary of derogations and exceptions see An overview of European competition rules applying in the agricultural sector, 2016, [https://ec.europa.eu/competition/sectors/agriculture/overview_european_ competition_rules_agricultural_sector.pdf], Accessed 9 April 2021

44 See Report from the Commission to the European Parliament and the Council on unfair business-to-business trading practices in the food supply chain, Brussels, 29.1.2016 COM (2016) 32 final, p. 3

45 Daskalova, V., Counterproductive Regulation? The EU's (Mis)Adventures in Regulating Unfair Trading Practices in the Food Supply Chain, 2018, [https://ssrn.com/abstract=3255435], Accessed 20 March 2021

46 Ibid.

47 Proposal for a Directive of The European Parliament and of the Council on unfair trading practices in business-to-business relationships in the food supply chain, Brussels, 12.4.2018, COM (2018) 173 final, 2018/0082(COD).

48 Ibid. 
on desirable features for national and voluntary governance frameworks. ${ }^{49}$ As a result, most of the MS implemented some form of national legislation to tackle the issue. While covering more or less similar practices, legislation instruments between MS varied: some of the MS integrated UTPs rules in the national competition law framework; some extended the consumer protection from unfair commercial practices to cover $\mathrm{B} 2 \mathrm{~B}$ relations; others enacted special $\mathrm{B} 2 \mathrm{~B}$ rules, either horizontal or limited to food and supply chain. ${ }^{50}$ Needless to say, this process led to numerous divergences between national legislative frameworks, pressuring the Commission to unify the rules at the EU level, which was done in 2019 with the UTP Directive.

So, what are these rules? Are they the extension of contract or competition law? The answer is not as simple as they belong to both and neither. Being somewhere in between, the new rules are diverging and overlapping with both, leading to possible undesirable spillover effects in contract law, and potential overlaps with competition law enforcement.

UTPs arise as in the context of a contractual relationship between the parties, subject to general contract law which is characterized by dispositive norms and parties' autonomy. Before the enactment of the UTPs Act, in Croatia general contract rules covered by the Obligations Act applied to most UTPs situations in B2B relations. ${ }^{51}$ Specific protection was granted only against a limited list of UTPs under the Trade $\mathrm{Act}^{52}$ and a number of UTPs under the Consumer act, ${ }^{53}$ which is however not applicable to B2B relations. Beside the notion of the UTPs, common to these rules is their private enforcement before national courts.

During the preparatory stage of the Directive, it has been established that traditional reliance on contract law remedies is faulty in the case of UTPs in food and

49 As a stricter unilateral conduct rules envisaged under article 3 (2) of the Regulation $1 / 2003$, OJ L [2003] $1 / 1$

50 For an attempt of systematic classification of national legislation on the topic see Fałkowski, J.; Ménard, C.; Sexton, J. R.; Swinnen J.; Vandevelde, S., Unfair trading practices in the food supply chain: A literature review on methodologies, impacts and regulatory aspects, 2017, [file:///D:/Users/Korisnik/ Downloads/jrc_report_utps_final\%20(1).pdf],pp. 44-45, Accessed 10 March 2021

51 Under these rules, the provisions of the general terms and conditions of the contract which, contrary to the principle of good faith and fairness, cause obvious inequality in the rights and obligations of the parties to the detriment of the co-contractor, or jeopardize the achievement of the purpose of the contract, are null and void. Article 296 of the Obligations Act, Official Gazette No. 35/2005, 125/2011, 78/2015, 29/2018

52 Articles 63 and 64 of the Trade Act, Official Gazette, No. 87/2008, 96/2008, 116/2008, 114/2011, 68/2013, 30/2014

53 Consumer Act, Official Gazette No. 41/2014, 110/2015, 14/2019 
supply chain, mostly due to the fear factor of commercial retaliation, ${ }^{54}$ such as delisting products or reducing the quantities of products ordered. ${ }^{55}$ It is predominantly in this context that the enforcement structure of the UTPs departed from private law mechanism and entered the realm of public, administrative enforcement, very much resembling the enforcement of competition law. The designated enforcement body in Croatia, the CCA is an independent body with public authority and as such it does not fit into the traditional institutional divide between the executive, judicial and legislative branch. Consequently, it is not given the authority to conduct misdemeanour procedures against misdemeanour offences. Therefore, to enable the CCA to impose fines it was necessary to bypass the provisions of the Misdemeanour Act. ${ }^{56}$ This has been done by treating UTPs as offences sui generis, ${ }^{57}$ just like competition law violations. There are no other sui generis offences in the Croatian legal system to the best of our knowledge. ${ }^{58}$ This fact alone indicates the ambiguous legal nature of UTPs and the institutional enforcement design as well as their similarity with competition law violations.

We may observe that up to the enactment of the UTPs Act, in the Croatian legislative framework any kind of ex post administrative intervention in contractual relationship between trading parties ${ }^{59}$ was unthinkable outside the context of competition law. ${ }^{60}$ Competition law consists of rules to ensure a level playing field for all undertakings competing on the market. It sets clear competition rules and defines limits of undertakings' freedom of action. In other words, competition

54 UTP Directive, para 8 of the Preamble

55 UTP Directive, para 25 of the Preamble

56 Misdemeanor Act, Official Gazette No. 107/2007, 39/2013, 157/2013, 110/2015, 70/2017, $118 / 2018$

57 Croatian Parliament, Proposal of the Act on the probibition of unfair trading practices in the business-to-business food supply chain, introductory remakrs, May 2017, [https://sabor.hr/sites/default/files/ uploads/sabor/2019-01-18/081259/PZ_144.pdf], Accessed 30 March 2021

58 For an extensive analysis of sui generis offences see Butorac Malnar, V.; Pecotić Kaufman, J., The interaction between $E U$ regulatory implants and the existing Croatian legal order in competition law, in: Kovač, M.; Vandenberghe, A. (eds.), Economic Evidence in EU Competition Law, Intersentia, Zagreb, 2016, pp. 327-356

59 As opposed to ex ante sectoral regulation conducted by different regulatory agencies, such as HAKOM or HERA.

60 For a more protective and interventionist approach in B2B contractual relations see Germany's extension of competition law in relation to unilateral conduct of undertakings with relative or superior market power under $\$ 20$ of Act against Restraints of Competition in the version published on 26 June 2013, Federal Law Gazette I, 2013, p. 1750, 3245 as last amended by Article 10 of the Act of 12 July 2018, Federal Law Gazette I, p. 1151. For a short overview, see Glöckner, J., Unfair trading practices in the supply chain and the co-ordination of European contract, competition and unfair competition law in their reaction to disparities in bargaining power, Journal of Intellectual Property Law \& Practice, Vol. 12, No. 5, 2017, pp 416-434. UTP Directive, para 1 of the Preamble. 
law imposes limitations on the contractual freedom for the sake of a higher good - the protection of a competitive process ${ }^{61}$ across sectors as the best mechanism for the efficient allocation of resources. ${ }^{62}$ However, when it comes to contractual interventions in B2B relations outside competition law context, one may rightfully question the legitimacy of protection of any interest overriding the party autonomy. According to the Directive, the protection against unfair trading practices should be introduced "to reduce the occurrence of such practices that are likely to negatively impact the living standards of the agricultural community." 63 Without undermining the importance of this goal and sector to which it relates, one may not but question whether such a goal could be attributed to some other sectors featuring similar market structures and threats, leading to fragmented, sector specific regulation, eroding the basic principles of general contract law.

The UTPs Act and competition law obviously do not pursue the same goals, nor do they use the same concepts and assessment criteria. Yet, the same activities might represent the violation of both laws. This is because they both sanction the unfairness resulting from strong market power. This becomes obvious when we investigate the wording of Article 102 (a) TFEU, according to which the abuse of dominant position may consist of direct or indirect imposition of unfair purchase or selling prices or other unfair trading conditions. ${ }^{64}$ The same is included in the national Competition Law Act. In this sense, sometimes the point of divergence will be a question of dominance threshold rather than substance, as both sets of rules are rooted in the concept of fairness. ${ }^{65}$ Having said that, it is necessary to identify the relationship between the two legislative frameworks in situations of overlap, i.e., would they both apply, or would one override the other. The answer is not straight forward, as competition law and UTPs Act, despite all the underlying similarities, are complementary to each other, and are not in relation of lex generali and lex specials. If one of the listed UTPs would be included in the contract within the scope of the UTPs Act and would simultaneously distort competi-

${ }_{61}$ The goals of EU comeptition have always been debated. In a recently conducted emirical study of CJEU case-law, a variety of comeptitiion law goals have been identified: efficiency, welfare, economic freedom and protection of competitors, competition structure, fairness, single market integration, and competition process. See Stylianou, K.; Iacovides, M., The Goals of EU Competition Law - A Comprehensive Empirical Investigation, 2020, [https://ssrn.com/abstract=3735795], Accessed 28 March 2021

62 Bailey, D.; John, E. L. (eds.), Bellamy \& Child European Union Law of Competition, $8^{\text {th }}$ edition, Oxford University Press, Oxford, 2018, para 1.016.

63 Ibid.

64 Most exploitative abuses of dominant position fall under this category.

65 For a detailed comparative analysis of the concept of fairness see Abdollah Dehdashti S., B2B unfair trade practices and EU competition law, European Competition Journal, Vol. 14, No 2-3, 2018, pp. 305-341 
tion within the meaning of Art 101/102 TFEU or the corresponding violations of Croatian Competition Act, all of the rules would be applicable. However, would it run counter to the principle of ne bis in idem, to prosecute the same undertaking for the same conduct twice, under different legal grounds? In the context of competition law, the answer to this question is clear as it has been addressed by the CJEU who stated "that principle thus precludes an undertaking being found liable or proceedings being brought against it afresh on the grounds of anti-competitive conduct for which it has been penalised or declared not liable by an earlier decision that can no longer be challenged." 66 The reservation here is related to the fact, that UTPs Act and competition law, do not pursue the same goals, thus the infringement, although being done by the same undertaking would be pursued and sanctioned for different purposes. This raises serious concerns of legal certainty. In addition, double proceedings undermine institutional efficiency, as both would be conducted by the same body, under similar but nevertheless different procedures, assessment and sanctions. This point of confusion should be cleared most straightforwardly.

Legal reasoning leads towards the overriding applicability of competition law rules over UTPs Act. This is particularly the case with Articles 101 and 102 TFEU. If for nothing else, then on the account of the hierarchy of EU legal norms. Being prescribed under EU primary law and applicable across sectors, ${ }^{67}$ they should take precedence over any implementing national law of the UTP Directive as a secondary EU law source. In that regard, some form of coordination would be necessary, particularly between the Commission and national enforcement bodies of UTPs legislation. The same reasoning should apply in case of simultaneous application of EU and national competition rules by national competition authorities (NCAs) under Article 3 (1) of the Regulation 1/2003. However, when it comes to the overlapping competence of UTPs Act and national competition rules, the answer is not straightforward. Not being in a hierarchical relationship, competition law enforcement's choice is justifiable on different grounds - a more holistic approach and broader intervention. It is plausible that UTPs would represent only one segment of the competition law infringement which often tends to be a complex combination of different anticompetitive strategies. In that sense, remedies and sanctions under the UTPs Act could resolve the problem between the contracting parties, while the competition law issue would not necessarily be resolved. This could potentially lead towards split proceedings. This solution is not satisfactory either. It is well known that competition law infringements may comprise a com-

66 Case C-17/10 Toshiba Corporation [2012], ECLI:EU:C:2012:72, par. 94

67 As already mentioned earlier, there are some derogations and exemptions of EU comeptition law in the agrecultural sector, however it does not extend to UTPs. 
bination of strategies distorting competition with combined force and are thus often being treated as a single competition law infringement. To the contrary, if competition law would override the applicability of the UTPs Act in cases of overlap, the sanctions and remedies in that proceedings could solve both the unfairness of contractual relation between the parties and the related competition law issue. Such a solution would create more legal certainty for the parties and would lead to a more efficient enforcement.

We have stated initially that UTPs regulation is somewhere in between contract and competition law. While the relationship with contract law is not as blurry, as these rules are in lex specialis-lex generali relation, the concerns are arising from the possible undesirable spillover effects from UTPs into general contract law, as analyzed in the following section.

\section{POSSIBLE SPILL OVER EFFECTS TO OTHER B2B CONTRACTS}

As UTP Directive applies to B2B contracts in the food supply chain, authors consider it worth analyzing the possible effect this Directive could have on all B2B contracts ${ }^{68}$ It would not be the first time a directive with a much narrower scope of application influenced a significantly broader set of legal relations. An example would be the Directive 1999/44, ${ }^{69}$ which aimed the consumer contracts but influenced B2B contract law in many EU countries regarding the conformity of the goods in the sale of goods contract. ${ }^{70}$ Thus, the authors shall analyze the possible effects of UTP Directive and compare them to existing legal instruments to unify the sale of goods contract. Authors shall consider UNIDROIT Principles of International Commercial Contracts (hereinafter UNIDROIT Principles) ${ }^{71}$, Principles of European Contract Law (hereinafter PECL) and United Nations Convention on Contracts for the International Sale of Goods (hereinafter CISG) ${ }^{72}$ for analyzing the status of unequal bargaining power in the international commercial sale of goods contracts.

68 See also Daskalova, V., op. cit., note 9, p. 28

69 Directive 1999/44/EC of the European Parliament and of the Council of 25 May 1999 on certain aspects of the sale of consumer goods and associated guarantees [1999] OJ L 171

70 Petrić, S., Odgovornost za materijalne nedostatke stvari prema novom Zakonu o obveznim odnosima, Zbornik Pravnog fakulteta Sveučilišta u Rijeci, Vol. 27, No. 1, 2006, pp. 87-128, p. 99.

71 International Institute for the Unification of Private Law (UNIDROIT), Unidroit Principles of International Commercial Contracts, 2016, [https:/www.unidroit.org/instruments/commercial-contracts/ unidroit-principles-2016], Accessed 25 March 2021

72 United Nations Commission on International Trade Law, United Nations Convention on Contracts for the International Sale of Goods, (Vienna, 1980) (CISG) [https://uncitral.un.org/en/texts/salegoods/ conventions/sale_of_goods/cisg], Accessed 20 March 2021 
Unequal bargaining power is a standard widely recognized in contract law, and it is relevant to more stages of contracts, from its formation, interpretation and possible contract remedies. ${ }^{73}$ Even if the parties or the court do not expressly state the inequality of bargaining skill as the ground for their claim / judgement, this standard can be embedded in other contractual concepts, such as contra preferentem rule, reasonable expectations doctrine and others. ${ }^{74}$ The challenge is that although the importance of unequal bargaining power is recognized, the concept remains ambiguous. ${ }^{75}$ Traditionally, bargaining and negotiating problems between the parties are connected to the precontractual phase, where parties who breach their duties in bargaining/negotiating can be subject to precontractual liability. This liability stems from the good faith and duty of care principles. ${ }^{76}$ However, the precontractual liability is mostly recognized in situations when the contract did not occur, while any breach after the contract is concluded shall most likely fall within the contractual liability. ${ }^{77}$

In a $\mathrm{B} 2 \mathrm{~B}$ sale of goods contract, it can be challenging to prove the inequality of bargaining skill which should trigger certain legal consequences. ${ }^{78}$ On the other hand, courts are traditionally more willing to allow certain groups to claim unequal bargaining power, where the most prominent example would be consumers. ${ }^{79}$ Protection of consumers is in the focal point of EU legislature with many EU directives and regulation that intervene in Member States' contractual law to ensure the protection of the weaker party-the consumer. ${ }^{80}$ However, in B2B transactions there was no such presumption until the UTP Directive came into force.

73 See also Barnhizer, D. D., Inequality of Bargaining Power, University of Colorado Law Review, Vol. 76, No. 1, 2005, pp. 139-242, p. 144.

$74 \quad$ Ibid., p. 149.

75 See Helveston, M.; Jacobs, M., The Incoherent Role of Bargaining Power in Contract Law, Wake Forest Law Review, Vol. 49, No. 4, 2014, pp. 1017-1058, p. 1021; Schwartz, A., Seller Unequal Bargaining Power and the Judicial Process, Indiana Law Journal, Vol. 49, No. 3, 1974, pp. 367-398, p. 392.

76 See Braut Filipović, M.; Tomulić Vehovec, M., Precontractual Liability in Eu And Croatian Law, Harmonius Journal of Legal and Social Studies in South East Europe, Vol. 1, No. 1, 2012, pp. 13-32, p. 15.

77 It is rather an exception if the parties can invoke the precontractual liabiliy after the contract is concluded. Different legal standings on this matter can be found throughout the MSs. See Cartwright, J.; Hesselink, M., Precontractual Liability in European Private Law, Cambridge University Press, 2008, p. 362 and further.

78 Adler, R. S.; Silverstein, E. M., When David Meets Goliath: Dealing With Power Differentials in Negotiations, Harvard Negotiation Law Review, Vol. 5, 2000, pp. 1-112, p. 54. From the American court practice, see for example case Coursey v. Caterpillar, Inc., No. 94-1348, 1995, (6th Cir. Aug. 6, 1995), where the court stated: "Unconscionability is rarely found to exist in a commercial setting.". For other examples and views from American theory and practice see Choi, A.; Triantis, G., The Effect of Bargaining Power on Contract Design, Virginia Law Review, Vol. 98, No. 8, 2012, pp. 1665-1744, p. 1730.

79 Barnhizer, D. D., op. cit., p. 150.

80 See Mišćenić, E., Europsko privatno pravo: posebni dio, Školska knjiga, Zagreb, 2021, pp. 22 et seq. 
UTP Directive explicitly correlates the evaluation of bargaining power of the contractual parties to their financial strength. Precisely, it says: "A suitable approximation for relative bargaining power is the annual turnover of the different operators." ${ }^{11}$ The EU legislator finds that such an approach offers a distinctive advantage to the contractual parties: "predictability concerning their rights and obligations under this Directive" ${ }^{82}$ It must be noted that the existence of bargaining power in any contractual relationship, including those in the vertical relationship in the food supply chain, does not and should not presume the abuse of that power. ${ }^{83}$ However, UTP Directive significantly enhances the position of the sellers of the agricultural products, as the very existence of one of the defined UTPs coupled with the existence of the unequal bargaining power due to different financial strength of the parties, presents a breach of the contract by the buyer. Sanctions for such a breach vary depending on the national law, ${ }^{84}$ where Croatian legislature opted for a nullity of a particular contractual provision ${ }^{85}$ and fines. ${ }^{86}$

In fact, we could argue that UTP Directive and Croatian UTPs Act introduce an irrefutable assumption that a buyer with a defined financial income holds significant bargaining power in the contractual relationship. This is an irrefutable assumption as the law provides no possibility for the buyer to prove otherwise. Further, if one of the parties has significant bargaining power and the sale of goods contract has a provision which represents the UTPs as defined by the UTP Directive and Croatian UTPs Act, this also represents an irrefutable assumption that the UTP occurred, ${ }^{87}$ and the buyer suffers sanctions - possible nullity of the contractual provision and fines. ${ }^{88}$ Such a result reflects upon contractual liability, where the seller can sue for damages, outside of possible penalties by the competent body. The seller can also rely on the irrefutable assumption that the unequal bargaining power exists and, coupled with the UTPs in the contract, claim damages.

\footnotetext{
81 Par. 14 of the Preamble of UTP Directive

82 Par. 14 of the Preamble of UTP Directive

83 See Commission Staff Working Document, Impact Assessment: Initiative to improve the food supply chain (unfair trading practices), SWD(2018) 92 final, p. 21. That is also the standopint taken in the UNIDROIT Principles. See International Institute for the Unification of Private Law (UNIDROIT), Unidroit Principles of International Commercial Contracts, op. cit., p. 110.

84 Cafaggi F.; Iamiceli, P., op. cit, note 21, p. 30

85 For nullity of a certain provision see for example article 9 of the Act on the Prohibition of Unfair Trade Practices in the Food Supply Chain. Before the amendment from 2021, it was provided that the entire sale of goods is null if it is not conluded in a written form and if it does not have all the obligatory provisions. See former article 6 of the UTPs Act from 2017.

86 See Article 24 of the UTPs Act

87 See also Brnabić, R.; Ivkošić, M., Zakonsko uređenje nepoštenih trgovačkih praksi - otvorena pitanja, Zbornik 56. susreta pravnika, Opatija, 2018, pp. 109-139, p. 128

88 See Articles 9 and 24 of the UTPs Act
} 
Thus, UTP Directive introduces a significant exemption to B2B sale of goods contract. Although its scope of application is relatively narrow - it applies solely to the sale of goods contract concerning the food supply chain, authors shall present the status and significance of unequal bargaining power in existing international instruments for the unification of the sale of goods contracts, especially in B2B transactions.

The most famous and widespread instrument for unification of the commercial sale of goods contract is the CISG ${ }^{89}$ However, it is expressly provided that it does not cover the issue of validity of the contract, ${ }^{90}$ while it is highly questionable whether the negotiations and precontractual liability fall within the scope of the CISG. ${ }^{91}$ Thus, two most typical claims connected with the unequal bargaining power fall outside of the scope of the CISG. However, that does not mean that the drafters of the CISG were unaware of this particular challenge for the parties, and they have in fact associated it with the presumably weaker bargaining power for the parties coming from transitioning and developing countries. For that reason, in the CISG were embedded a more simple and flexible provisions regarding the non-conformity of the goods and remedies for breach of the contract. ${ }^{22}$ For example, the time limit set for giving the notice for lack of conformity can be extended if there was a "reasonable excuse" for failure, ${ }^{93}$ and this possibility was introduced by having in mind the parties from the developing countries who might lack the knowledge for the examination of the complex goods in due time. ${ }^{94}$ But we can only conclude that although the CISG tackled certain consequences of the parties' unequal position, it did not develop the standard of unequal bargaining powers of the parties and possible influence on the validity of the sale of goods contract. This issue remains within the national law applicable to a certain dispute or if the parties chose some of the available international instruments, such as UNIDROIT Principles or PECL.

89 There are currently 94 countries which adopted and ratified the CISG, which means that it has potential to cover most of the world international commercial sale of goods contract. See Status: United Nations Convention on Contracts for the International Sale of Goods (Vienna, 1980) (CISG) [https:// uncitral.un.org/en/texts/salegoods/conventions/sale_of_goods/cisg/status], Accessed 3 April 2021

90 See Article 4 of the CISG

91 For an overview see Goderre, D. M., International Negotiations Gone Sour: Precontractual Liability under the United Nations Sales Convention, University of Cincinnati Law Review, Vol. 66, No. 1, 1997, pp. 257-282

92 Schwenzer, I., The CISG - A Fair Balance of the Interests of the Seller and the Buyer, in: Schwenzer, I.; Pereira, C., Tripodi, L. (eds.), CISG and Latin America, Regional and Global Perspectives, The Hague, 2016, pp. 79-91

93 See Article 44 of the CISG

94 See Cañellas, A. M., The Scope Of Article 44 CISG, Journal of Law and Commerce, Vol. 25, 2005, pp. 261-271, p. 262 
UNIDROIT Principles provide in article 3.2.7. the parties can avoid the contract (not nullify) if "at the time of the conclusion of the contract, the contract or term unjustifiably gave the other party an excessive advantage." For deciding upon such a matter, one of the factors that should be considered is the "inexperience or lack of bargaining skill". ${ }^{55}$ Such a standard for possible avoidance of the contract concluded in B2B transactions is criticized, ${ }^{96}$ as some authors consider that such provision is not in accordance with the commercial practice where it is very often that one party has a stronger or weaker bargaining position due to various factors, such as the buyer's need for the goods, availability of alternate buyers or sellers and other. ${ }^{97}$ Official commentaries of the UNIDROIT Principles point out that the party can void the contract on these grounds if it results in a "gross disparity" between the contractual obligations, which is described to be "[...] so great as to shock the conscience of a reasonable person". ${ }^{98}$ In other words, the contract must be "unreasonably disadvantageous for one and unreasonably advantageous for the other party." ${ }^{99}$ However, this shall not cover the cases when one of the party has a dominant market position because it sells/buys rare things on the market. ${ }^{100}$ Applying this rule to the food supply chain, if the seller is dependent on the buyer to buy his/her products, the contract could be voided only if it provided an unreasonable advantage for the buyer. Otherwise, unequal bargaining power or lack of bargaining skill would not trigger the party's right for the avoidance of the contract. We can easily conclude that such a solution gives a much broader space for arguing from both parties whether the actual abuse of the bargaining powers occurred. The proof of the abuse would be on the seller of the agricultural products, which naturally would provide for an additional challenge.

This approach is followed by the PECL, which were generally drafted under the UNIDROIT Principles' influence, consisting of many identical provisions and reasoning. ${ }^{101}$ Article 4:109 resembles article 3.2.7. of the UNIDROIT Principles, as the ground for avoidance is also set to be an excessive benefit or unfair advantage due to, among others, if the party "[...] was [...] inexperienced or lacking

95 Par. 1a of Article 3.2.7. of Unidroit Principles.

96 Bortolotti, F., Drafting and Negotiating International Commercial Contracts, International Chamber of Commerce, Paris, 2017, p. 47.

${ }_{97}$ Hill, R., Businessman's view of the Unidroit Principles, Journal of International Arbitration, Vol. 13, No. 2, 1996, pp. 163-170, p. 166.

98 Unidroit Principles, op. cit., p. 110.

99 Drobnig, U.; Lando, O., Progressive codification of international trade law, 1982, [https://www.unidroit.org/english/documents/1982/study50/s-50-20-e.pdf], Accessed 3 April 2021

100 Loc. cit.

101 See Lando, O., Principles of European Contract Law and UNIDROIT Principles: Moving from Harmonisation to Unification?, Uniform Law Review, Vol. 8. No. 1-2, 2003, pp. 122 - 123 
in bargaining skill". The party who seeks the avoidance must prove that "[...] the other party took advantage of the first party's situation in a way which was grossly unfair or took an excessive benefit." 102 Thus, the conclusion is the same as for the possible application of the UNIDROIT Principles on the food supply chain.

To conclude, UTP Directive introduces a significant exemption to B2B sale of goods contract. First of all, it brings a very strict definition of unequal bargaining power. It ties the existence of unequal bargaining power to total annual profit of both contractual parties. For comparison, Croatian legislature defines criteria only for the buyers, irrespective of the fact if the actual seller (supplier) has the same, lower or higher income then the buyer, which can lead to the absurd situations that the bargaining power rests with the party who has lower financial incomes! Regardless, it seems that the UTP Directive strives to determine bargaining power in a very definite and predictable way, leaving no room for proving otherwise. Comparing such a solution to existing concepts of unequal bargaining power in contractual law, we find such a solution worrisome. The greatest concern is if such a definition and understanding of unequal bargaining power spills over B2B transaction outside the food supply chain. If the courts are already more willing to treat consumers as a weaker bargaining party, will they be now more willing to view traders with lower financial income in the same way? We strongly oppose to such a standpoint. Party autonomy, coupled with the liability concept where culpa levis might be presumed, but it is a refutable assumption, is in the heart of modern commercial contractual relationships. UTP Directive and national legislations, such as Croatian, significantly alter those understandings. Although there might be justified reasons to take such measures in the food supply chain, authors strongly oppose applying such understanding in other B2B sale of goods contract and other B2B transactions.

\section{CONCLUSION}

There is no doubt that food and supply chain in Europe is one of the most sensitive markets worthy of protection because of its crucial importance for the well being of EU citizens. The UTP Directive thus provides for a hybrid model of sectoral protection of $\mathrm{B} 2 \mathrm{~B}$ relations against UTPs, subjecting them to public enforcement. Having analysed the Croatian national legislation, the authors identified its scope of application as an incorrect transposition of the Directive, and offer de lege ferenda solutions in that regard. In addition, authors argue that it is very

102 See Von Rossum, M.M., Validity, in: Busch, D.; Hondious, E. H.; Kooten, H. J.; Schelhaas, H. N.; Schrama, W. M., The Principles of European Contract Law and Dutch Law: A Commentary, Kluwer Law International, 2002, pp. 191-214, p. 213 
unclear from the theoretical point of view, what is the appropriate legal systematization of these rules in the national legal system. The injustice in contractual relationship arising out of an unequal bargaining power has already been addressed by general contract law and consumer law. On the other hand, the competitive market distortions arising out the abuse of dominant market power is addressed by competition law. Being somewhere in between, UTPs regulation seems to fall out of the classical systematization of legal norms jeopardizing the coherency and the efficiency of enforcement. This transpires particularly in relation to competition law in overlapping scenarios, which remains very unclear and void of any normative guidance. Authors offer a variety of legal arguments in favour of the overriding applicability of competition rules in these situations. In addition, the UTP Directive introduces significant exemptions to B2B sale of goods contract. It determines bargaining power in a very definite and predictable way, tying it to the financial strength of the parties. The authors call for a pressing interpretative caution in order to avoid the detrimental impact of possible spillover effect of the standard of unequal bargaining power, as defined by the Directive 2019/633, to the sale of goods contract in other B2B transactions.

\section{REFERENCES}

\section{BOOKS AND ARTICLES}

1. Abdollah Dehdashti S., B2B unfair trade practices and EU competition law, European Competition Journal, Vol. 14, No 2-3, 2018, pp. 305-341

2. Adler, R. S.; Silverstein, E. M., When David Meets Goliath: Dealing With Power Differentials in Negotiations, Harvard Negotiation Law Review, Vol. 5, 2000, pp. 1-112

3. Bailey, D.; John, E. L. (eds.), Bellamy \& Child European Union Law of Competition, $8^{\text {th }}$ edition, Oxford University Press, Oxford, 2018

4. Barnhizer, D. D., Inequality of Bargaining Power, University of Colorado Law Review, Vol. 76, No. 1, 2005, pp. 139-242

5. Bortolotti, F., Drafting and Negotiating International Commercial Contracts, International Chamber of Commerce, Paris, 2017

6. Braut Filipović, M.; Tomulić Vehovec, M., Precontractual Liability in Eu And Croatian Law, Harmonius Journal of Legal and Social Studies in South East Europe, Vol. 1, No. 1, 2012, pp. 13-32

7. Braut-Filipović, M.; Zubović, A., Legal status of Croatian family farms, in: Sander, G.; Pošćić, A.; Martinović, A. (eds.), Exploring the Social Dimension of Europe, essays in honour of prof. Nada Bodiroga-Vukobrat, Verlag dr. Kovač, Hamburg, 2021, pp. 473-486

8. Brnabić, R.; Ivkošić, M., Zakonsko uređenje nepoštenih trgovačkih praksi-otvorena pitanja, Zbornik 56. susreta pravnika, Opatija, 2018, pp. 109-139

9. Brugger, W., Concretization of Law and Statutory Interpretation, Tulane European \& Civil Law Forum, Vol. 11, 1996, pp. 207-250 
10. Butorac Malnar, V.; Pecotić Kaufman, J., The interaction between EU regulatory implants and the existing Croatian legal order in competition law, in: Kovač, M.; Vandenberghe, A. (eds.), Economic Evidence in EU Competition Law, Intersentia, Zagreb, 2016, pp. 327-356

11. Cañellas, A. M., The Scope Of Article 44 CISG, Journal of Law and Commerce, Vol. 25, 2005, pp. 261-271

12. Caroccia F., Rethinking the Juridical System. Systematic Approach, Systemic Approach and Interpretation of Law, Italian Law Journal, Vol. 2, No. 1, 2016, pp. 65-85

13. Cartwright, J.; Hesselink, M., Precontractual Liability in European Private Law, Cambridge University Press, 2008

14. Choi, A.; Triantis, G., The Effect of Bargaining Power on Contract Design, Virginia Law Review, Vol. 98, No. 8, 2012, pp. 1665-1744

15. Daskalova, V., Regulating Unfair Trading Practices in the EU Agri-food Supply Chain: a Case of Counterproductive Regulation?, Yearbook of Antitrust and Regulatory Studies, Vol. 13, No. 21, 2020, pp. 7-53

16. Daskalova, V., The New Directive on Unfair Trading Practices and EU Competition Law, Journal of European Competition Law \& Practice, Vol. 10, No. 5, 2019, pp. 281-296

17. Glöckner, J., Unfair trading practices in the supply chain and the co-ordination of European contract, competition and unfair competition law in their reaction to disparities in bargaining power, Journal of Intellectual Property Law \& Practice, Vol. 12, No. 5, 2017, pp 416-434

18. Goderre, D. M., International Negotiations Gone Sour: Precontractual Liability under the United Nations Sales Convention, University of Cincinnati Law Review, Vol. 66, No. 1, 1997, pp. 257-282

19. Helveston, M.; Jacobs, M., The Incoherent Role of Bargaining Power in Contract Law, Wake Forest Law Review, Vol. 49, No. 4, 2014, pp. 1017-1058, p. 1021

20. Hill, R., Businessman's view of the Unidroit Principles, Journal of International Arbitration, Vol. 13, No. 2, 1996, pp. 163-170

21. Lando, O., Principles of European Contract Law and UNIDROIT Principles: Moving from Harmonisation to Unification?, Uniform Law Review, Vol. 8. No. 1-2, 2003, pp. 122 - 123

22. Mišćenić, E., Europsko privatno pravo: posebni dio, Školska knjiga, Zagreb, 2021

23. Mišćenić, E., Europsko privatno prvo: opći dio, Školska knjiga, Zagreb, 2019

24. Petrić, S., Odgovornost za materijalne nedostatke stvari prema novom Zakonu o obveznim odnosima, Zbornik Pravnog fakulteta Sveučilišta u Rijeci, Vol. 27, No. 1, 2006, pp. 87-128

25. Petrović, S., Pravni oblici pravnih osoba za obavljanje djelatnosti - pretpostavke i posljedice, Zbornik Pravnog fakulteta u Zagrebu, Vol. 56, special issue, 2006, pp. 87-127

26. Schwartz, A., Seller Unequal Bargaining Power and the Judicial Process, Indiana Law Journal, Vol. 49, No. 3, 1974, pp. 367-398

27. Schwenzer, I., The CISG - A Fair Balance of the Interests of the Seller and the Buyer, in: Schwenzer, I.; Pereira, C., Tripodi, L. (eds.), CISG and Latin America, Regional and Global Perspectives, The Hague, 2016, pp. 79-91

28. Visković, N., Teorija države i prava, Birotehnika, Zagreb, 2001 
29. Von Rossum, M.M., Validity, in: Busch, D.; Hondious, E. H.; Kooten, H. J.; Schelhaas, H. N.; Schrama, W. M., The Principles of European Contract Law and Dutch Law: A Commentary, Kluwer Law International, 2002, pp. 191-214

\section{COURT OF JUSTICE OF THE EUROPEAN UNION}

1. Case C-17/10 Toshiba Corporation [2012], ECLI:EU:C:2012:72

\section{EU LAW}

1. Annex to Commission Recommendation 2003/361/EC of 6 May 2003 concerning the definition of micro, small and medium-sized enterprises [2003] OJ L 124

2. Commission Staff Working Document, Impact Assessment: Initiative to improve the food supply chain (unfair trading practices), SWD(2018) 92 final

3. Communication from The Commission to The European Parliament, The Council, The European Economic and Social Committee and The Committee of The Regions Tackling unfair trading practices in the business-to-business food supply chain, COM/2014/0472 final.

4. Directive (EU) 2019/633 of the European Parliament and of the Council of 17 April 2019 on unfair trading practices in business-to-business relationships in the agricultural and food supply chain [2019] OJ L 111

5. Directive 1999/44/EC of the European Parliament and of the Council of 25 May 1999 on certain aspects of the sale of consumer goods and associated guarantees [1999] OJ L 171

6. Directive 2005/29/EC of The European Parliament and of the Council of 11 May 2005 concerning unfair business-to-consumer commercial practices in the internal market and amending Council Directive 84/450/EEC, Directives 97/7/EC, 98/27/EC and 2002/65/ EC of the European Parliament and of the Council and Regulation (EC) No 2006/2004 of the European Parliament and of the Council ('Unfair Commercial Practices Directive') OJ L [2005] 29/1 amended by Directive (EU) 2019/2161 of the European Parliament and of the Council of 27 November 2019 amending Council Directive 93/13/EEC and Directives 98/6/EC, 2005/29/EC and 2011/83/EU of the European Parliament and of the Council as regards the better enforcement and modernisation of Union consumer protection rules (Text with EEA relevance), [2019] OJ L 327/7

7. Directive 2006/114/EC of the European Parliament and of the Council of 12 December 2006 concerning misleading and comparative advertising [2006] OJ L 376/21

8. Directive 2011/7/EU of the European Parliament and of the Council of 16 February 2011 on combating late payment in commercial transactions [2011] OJ L 48/1

9. Proposal for a Directive of The European Parliament and of the Council on unfair trading practices in business-to-business relationships in the food supply chain, Brussels, 12.4.2018, COM (2018) 173 final, 2018/0082(COD)

10. Regulation (EU) 2017/2393 of the European Parliament and of the Council of 13 December 2017 [2017] OJ L 350/15

11. Regulation (EU) No 1308/2013 of the European Parliament and of the Council of 17 December 2013 establishing a common organisation of the markets in agricultural prod- 
ucts and repealing Council Regulations (EEC) No 922/72, (EEC) No 234/79, (EC) No 1037/2001 and (EC) No 1234/2007 (CMO Regulation)

12. Report from the Commission to the European Parliament and the Council on unfair business-to-business trading practices in the food supply chain, Brussels, 29.1.2016 COM (2016) 32 final

13. Treaty on the Functioning of the European Union (TFEU), OJ C 326, 26 October 2012, p. 47-390 (consolidated version)

\section{LIST OF NATIONAL REGULATIONS, ACTS AND COURT DECISIONS}

1. Act against Restraints of Competition in the version published on 26 June 2013, Federal Law Gazette I, 2013, p. 1750, 3245 as last amended by Article 10 of the Act of 12 July 2018, Federal Law Gazette I, p. 1151

2. Act on the prohibition of unfair trading practices in the business-to-business food supply chain, Official Gazette No. 117/2017

3. Companies Act, Official Gazette No. 111/1993, 34/1999, 121/1999, 52/2000, 118/2003, 107/2007, 146/2008, 137/2009, 125/2011, 152/2011, 111/2012, 68/2013, 110/2015, $40 / 2019$

4. Consumer Act, Official Gazette No. 41/2014, 110/2015, 14/2019

5. Coursey v. Caterpillar, Inc., No. 94-1348, 1995, (6th Cir. Aug. 6, 1995)

6. Law on Administrative Disputes, Official Gazette No. 20/2010, 143/2012, 152/2014, 94/2016, 29/2017

7. Misdemeanor Act, Official Gazette No. 107/2007, 39/2013, 157/2013, 110/2015, 70/2017, $118 / 2018$

8. Obligations Act, Official Gazette No. 35/2005, 125/2011, 78/2015, 29/2018

9. Trade Act, Official Gazette No. 87/2008, 96/2008, 116/2008, 114/2011, 68/2013, 30/2014

\section{WEBSITE REFERENCES}

1. An overview of European competition rules applying in the agricultural sector, 2016, [https:// ec.europa.eu/competition/sectors/agriculture/overview_european_competition_rules_agricultural_sector.pdf], Accessed 9 April 2021

2. Cafaggi F.; Iamiceli, P., Unfair Trading Practices in the Business-to-Business Retail Supply Chain - An overview on EU Member States legislation and enforcement mechanisms, 2018, [https:// iris.unitn.it/retrieve/handle/11572/204123/224121/JRC\%20Report\%20(final).pdf], Accessed 10 March 2021

3. Cafaggi, F.; Iamiceli, P., Unfair Trading Practices in Food Supply Chains. Regulatory Responses and Institutional Alternatives in the Light of the New EU Directive, 2019, [https://ssrn.com/ abstract=3380355], Accessed 10 March 2021

4. Croatian Parliament, Explanatory memorandum of the Draft Law on the Amendments to the UTPs Act, 2021, [https://www.sabor.hr/hr/prijedlog-zakona-o-izmjenama-i-dopunama-zakona-o-zabrani-nepostenih-trgovackih-praksi-u-lancu], Accessed 2 April 2021 
5. Croatian Parliament, Proposal of the Act on the prohibition of unfair trading practices in the business-to-business food supply chain, introductory remakrs, May 2017, [https://sabor.hr/ sites/default/files/uploads/sabor/2019-01-18/081259/PZ_144.pdf], Accessed 30 March 2021

6. Daskalova, V., Counterproductive Regulation? The EU's (Mis)Adventures in Regulating Unfair Trading Practices in the Food Supply Chain, 2018, [https://ssrn.com/abstract=3255435], Accessed 20 March 2021

7. Drobnig, U.; Lando, O., Progressive codification of international trade law, 1982, [https:// www.unidroit.org/english/documents/1982/study50/s-50-20-e.pdf], Accessed 3 April 2021

8. Fałkowski, J.; Ménard, C.; Sexton, J. R.; Swinnen J.; Vandevelde, S., Unfair trading practices in the food supply chain: A literature review on methodologies, impacts and regulatory aspects, 2017, [file://D:/Users/Korisnik/Downloads/jrc_report_utps_final\%20(1).pdf], Accessed 10 March 2021

9. International Institute for the Unification of Private Law (UNIDROIT), Unidroit Principles of International Commercial Contracts, 2016, [https://www.unidroit.org/instruments/ commercial-contracts/unidroit-principles-2016], Accessed 25 March 2021

10. Ministry of Agriculture and Croatian Competition Agency, Odgovori na pitanja adresata Zakona o zabrani nepoštenih trgovačkih praksi u lancu opskrbe hranom, 2018, [http://www.aztn. $\mathrm{hr} /$ ea/wp-content/uploads/2017/12/Pro\%C4\%8Di\%C5\%A1\%C4\%87eni-tekst-Odgovora-na-pitanja-adresata-Zakona-o-zabrani-nepo\%C5\%A1 tenih-trgova $\%$ C4\%8Dkih-praksiu-lancu-opskrbe-hranom-ZNTP-od-5102018..pdf], Accessed 20 March 2021

11. Schebesta, H.; Purnhagen, K. P; Keirsbilck, B.; Verdonk, T., Unfair Trading Practices in the Food Chain: Regulating Right?, 2018, [https://ssrn.com/abstract=3267118], Accessed 25 March 2021

12. Stylianou, K.; Iacovides, M., The Goals of EU Competition Law - A Comprehensive Empirical Investigation, 2020, [https://ssrn.com/abstract=3735795], Accessed 28 March 2021

13. United Nations Commission on International Trade Law, Status: United Nations Convention on Contracts for the International Sale of Goods (Vienna, 1980) (CISG) [https://uncitral. un.org/en/texts/salegoods/conventions/sale_of_goods/cisg/status], Accessed 3 April 2021

14. United Nations Commission on International Trade Law, United Nations Convention on Contracts for the International Sale of Goods, (Vienna, 1980) (CISG) [https://uncitral.un.org/ en/texts/salegoods/conventions/sale_of_goods/cisg], Accessed 20 March 2021 